Komunike, Volume XI, No. 2, Desember 2019

\title{
STRATEGI KOMUNIKASI PONDOK PESANTREN DARUN NAJAH \\ DUMAN DALAM MENINGKATKAN RELIGIUSITAS MASYARAKAT DI \\ DESA DUMAN KEC. LINGSAR KAB. LOMBOK BARAT
}

\author{
Muhammad Syukri dan Zaenal Abidin \\ Universitas Islam Negeri Mataram \\ zabdiee@yahoo.com
}

\begin{abstract}
Abstrak
Pesantren merupakan lembaga pendidikan Islam yang sekurang-kurangnya mempunyai tiga ciri umum yaitu kyai sebagai figur sentral, asrama sebagai tempat tinggal para santri, masjid sebagai pusat kegiatan. Apapun ciri khususnya adalah adanya pemimpin yang kharismatik dan suasana keagamaan yang mendalam. Sebagai lembaga pendidikan, pesantren mempunyai misi sangat luas dan komplek, yang paling mendasar adalah pemahaman terhadap agama dan dakwah islamiyah. Pondok Pesantren Darun Najah Duman merupakan salah satu pondok pesantren yang ada di Lombok Barat dan satu-satunya pondok pesantren yang ada di desa Duman Kec. Lingsar. Alamsyah Ratu Perwiranegara mengemukakan beberapa pola umum yang khas dalam pendidikan Islam tradisional pesantren sebagai berikut: Independen, Kepemimpinan Tunggal, Kebersamaan dalam hidup yang merefleksikan kerukunan, Kegotong-royongan, Motivasi yang terarah dan pada umumnya mengarah pada peningkatan kehidupan beragama. Itulah beberapa ajaran yang disampaikan pesantren dalam rangka religiusitas untuk kehidupan masyarakat ke depannya. Dampak positif strategi komunikasi pondok peantren Darun Najah dalam meningkatkan religiusitas masyarakat di desa Duman adalah: a. terjalinnya komunikasi antar lembaga/Internal pesantren. b. terciptanya hubungan religious antara masyarakat. c. terciptanya keharmonisan di desa Duman.
\end{abstract}

Kata kunci: Strategi, komunikasi, religius 
Komunike, Volume XI, No. 2, Desember 2019

\section{A. Latar Belakang}

Kehadiran pesantren saat ini menjadi titik sentral kajian para ahli, karena nuansa-nuansa yang dicanangkan dan dilaksanakan dalam pesantren sangat unik. Tidak sedikit para ahli mengkritik atau juga melihat segi positifnya, karena kondisinya yang serba lain. ${ }^{1}$

Pesantren merupakan lembaga pendidikan Islam yang sekurangkurangnya mempunyai tiga ciri umum yaitu kyai sebagai figur sentral, asrama sebagai tempat tinggal para santri, masjid sebagai pusat kegiatan. Apapun ciri khususnya adalah adanya pemimpin yang kharismatik dan suasana keagamaan yang mendalam. sendiri bahwa pesantren tidak lepas Sebagai lembaga pendidikan, dari namanya komunikasi yang baik pesantren mempunyai misi sangat dalam menarik simpati masyarakat luas dan komplek, yang paling

\begin{tabular}{lll}
\hline & Abdul & Mujid dan \\
Mudzakkir, & $\quad$ /lmu & Pendidikan \\
(Jakarta: & Kencana & Prenada \\
2006), h. & 239. &
\end{tabular}

Yusuf

Islam Media.. mendasar adalah pemahaman terhadap agama dan dakwah islamiyah. $^{2}$

\section{Sehingga sejarah masuknya} agama Islam di Indonesia adalah karena penyebaran agama Islam oleh mubaligh-mubaligh dengan penerangan dan amalan serta melalui pondok pesantren. Kemudian mengalami perkembangan dan pertumbuhan sesuai dengan keadaan, waktu, dan tempat. Tegaknya sebuah pesantren sekurang-kurangnya harus didukung oleh lima unsur yaitu adanya pondok, masjid, pengajaran kitabkitab klasik, santri dan kyai. $^{3}$

Dalam perkembangannya

2 Mansur dan Mahfud Junaedi, Rekonstruksi Sejarah Pendidikan Islam di Indonesia (Jakarta: Departemen Agama RI, 2005 ), h. 96.

3 Ibid, h. 97. 
Komunike, Volume XI, No. 2, Desember 2019

dan menambah pemahaman agama menuju kehidupan yang lebih baik masyarakat guna meningkatkan dan bermanfaat sangat diperhatikan religiusitasnya. Semua itu terjadi sekali tingkat sosialisasinya.

karena peran pondok pesantren Komunikasi sebagai ilmu yang dalam menggunakan komunikasi mempelajari perilaku manusia dalam sebagai salah satu cara untuk berkomunikasi tentunya memiliki mempengaruhi pemahaman peran dalam mempengaruhi tingkat masyarakat dengan sistem pemahaman masyarakat dalam pengajaran agama untuk menjadikan meningkatkan tingkat keimanannya. sebagai landasan hidup masyarakat Adapun model komunikasi yang Islam pada umumnya. dipakai sebuah lembaga pendidikan Sesuai dengan perannya, seperti pesantren pada umumnya pesantren dipandang sebagai ruang sangat beragam untuk khusus sosial masyarakat. Hal ini mempengaruhi pemahaman dapat dilihat dalam kehidupan sosial masyarakat.

kemasyarakatan, dan terbukti Meski sudah banyak model memiliki andil yang cukup besar yang dipakai dalam komunikasi dalam perubahan sosial. Sebagai untuk memudahkan pemahaman lembaga pendidikan bagi masyarakat terhadap proses komunikasi dan pesantren memiliki kontrol sosial tingkat keimanan masyarakat. yang tinggi dalam menyelaraskan Namun tantangan dan cobaan kehidupan masyarakat. Dalam dalam proses mempengaruhi prakteknya bahwa komunikasi pemahaman dan merubah keyakinan pondok pesantren dalam masyarakat pada umum-nya pasti mempengaruhi dan merubah sikap sangat tidak mudah. Di samping dan tingkah laku masyarakat kemajuan zaman yang sudah 
Komunike, Volume XI, No. 2, Desember 2019

modern dan persaingan ilmu kepada masyarakat, dan ketiga, pengetahuan sudah pasti sangat beliau kasihan kepada akses sulit untuk sebuah Pondok pendidikan anak-anak sangat Pesantren dalam menyebarkan misi terbatas, karena hanya belajar di dakwah kepada masyarakat atau Paud/MI saja dan untuk mad'unya jika tidak melakukan melanjutkan pendidikan kejenjang terobosan dalam berdakwah. yang lebih tinggi sangat sulit

Sebagai salah satu pondok mereka dapatkan. Berdirinya Pondok pesantren, Darun Najah mengalami Pesantren ini sebagai lembaga hal yang sama. la juga mengalami pendidikan menengah pertama yang tantangan untuk bisa melakukan ada di Desa Duman. ${ }^{4}$

fungsi dan tugasanya. Pondok B. Gambaran Umum Pondok Pesantren Darun Najah awalnya Pesantren Darun Najah Duman berdiri sejak bulan Maret tahun Awalnya Pondok Pesantren 1983 yang didirikan oleh Bapak Darun Najah Duman ini berdiri TGH. Muhammad Anwar Mz. pada tahun 1983 dengan beberapa Adapun beliau mendirikan Pondok alasan yang melatarbelakangi Pesantren Darun Najah dengan berdirinya antara lain karena TGH. beberapa alasan yang mendukung Muhammad Anwar $\mathrm{Mz}$ prihatin situasi dan kondisi. Pertama, Tuan dengan keadaan pendidikan pada Guru perihatin terhadap tempat masa itu yang tidak memiliki dilaksanakannya pengajian berupa sekolah lanjutan seperti MTs surau-surau kecil beratapkan daun ataupun SMP, sehingga anak-anak ilalang. Kedua, yaitu beliau juga yang tamat SD di Desa itu tidak berdakwah dari masjid ke masjid untuk menyebarkan dakwah Islam

4 TGH. Muhammad Anwar Mz, Wawancara, Duman, 14 Desember 2012. 
Komunike, Volume XI, No. 2, Desember 2019

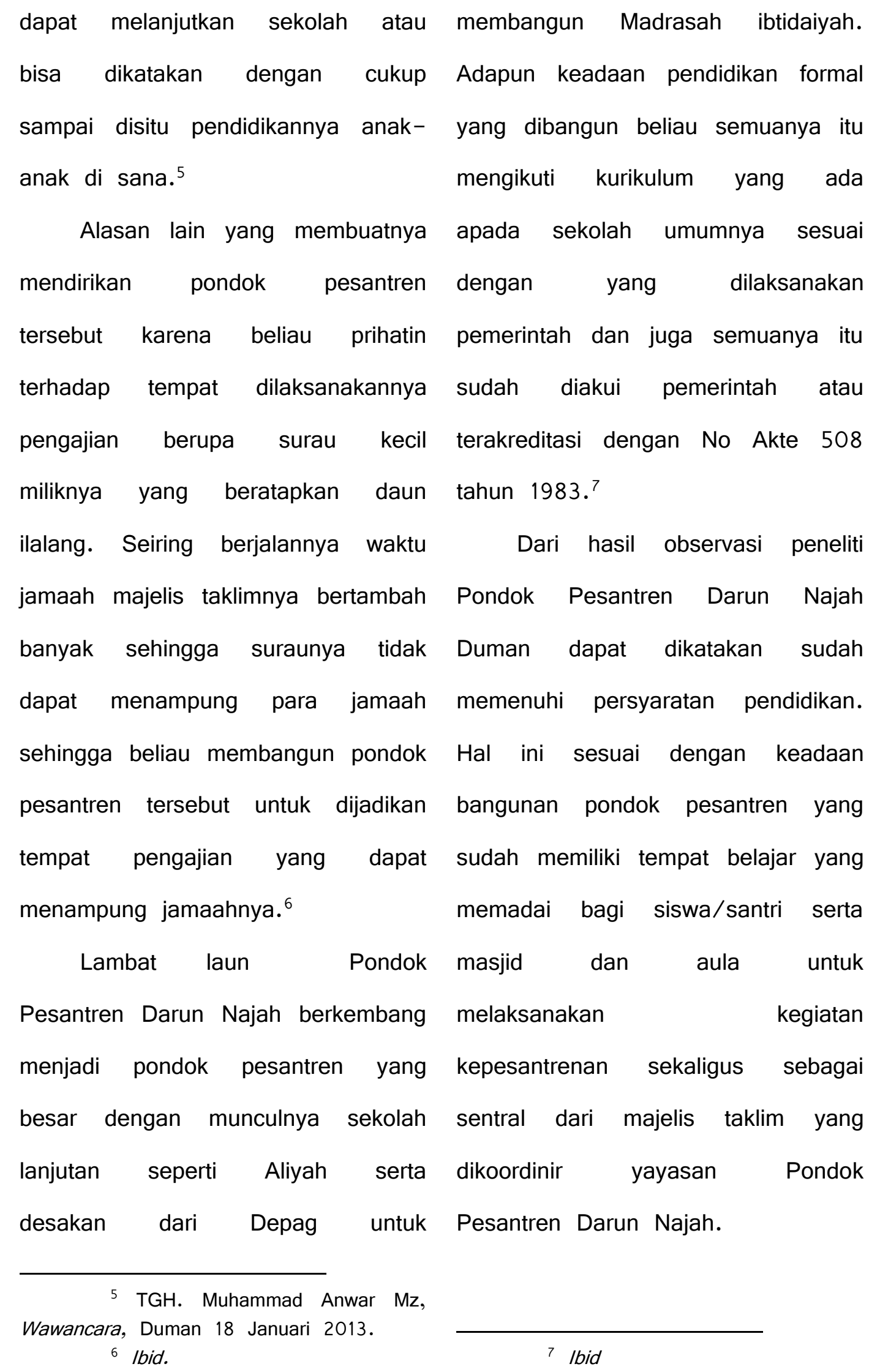


Komunike, Volume XI, No. 2, Desember 2019

Pondok Pesantren Darun terbukti dari banyaknya pendidikan Najah merupakan salah satu formal yang diselenggarakan. ${ }^{8}$ pondok pesantren yang ada di C. Strategi Komunikasi Pondok Lombok Barat dan satu-satunya Pesantren pondok pesantren yang ada di Strategi pada hakikatnya desa Duman Kec. Lingsar, dengan perencanaan (planning) dan luas wilayah kurang lebih 1,4 $\mathrm{Ha}$. manajemen (management) untuk Adapun batas-batas wilayah Pondok mencapai suatu tujuan. ${ }^{9} \mathrm{Di}$ dalam Pesantren Darun Najah Duman Kamus Besar Bahasa Indonesia adalah: dijelaskan tentang definisi strategi

a. Sebelah Barat: Desa Dasan Geria yaitu rencana yang cermat b. Sebelah Timur: Desa Langko mengenai kegiatan untuk mencapai c. Sebelah Utara:Desa Sayang-sayang sasaran khusus. ${ }^{10}$

d. Sebelah Selatan: Desa Segerongan Tingkat-tingkat strategi: Letak geografis pondok Enterprise Strategy, Corporate pesantren memang strategis sekali, Strategy, dan Business Strategy karena dapat dijangkau dengan jalur Tingkat-tingkat strategi itu transportasi, sehingga mudah merupakan kesatuan yang bulat dan dijangkau oleh siswa/santri yang menjadi isyarat bagi setiap belajar di sana serta masyarakat pengambil keputusan tertinggi bahwa pada umumnya. Dengan letak geografis tersebut Pondok Pesantren Darun Najah Duman mengalami perkembangan yang sangat pesat dari tahun ke tahun. Hal ini

8 Observasi, Pada hari Jum'at dan Sabtu 13-14 Maret 2012

9 Onong Uchjana Effenndy, IImu dan komunikasi teori dan praktek (Bandung: PT Remaja Rosdakarya, 2007 ), h. 32.

10 DEPDIKBUD, Kamus Besar Bahasa Indonesia, (Jakarta: Balai Pustaka, 2002 ), h, 1092. 
Komunike, Volume XI, No. 2, Desember 2019

mengelola organisasi tidak boleh Perdebatan, Diskusi, Pendidikan, dilihat dari sudut kerapian Memajukan Kebudayaan, Hiburan, administratif semata, tetapi juga dan Integrasi. Sedangkan hendaknya memperhitungkan soal komunikasi; Supaya yang kita "kesehatan" organisasi dari sudut sampaikan itu dapat dimengerti, ekonomi. Memahami orang lain, Supaya Istilah komunikasi dalam gagasan kita dapat diterima oleh bahasa Inggrisnya disebut dengan orang lain, Menggerakan orang lain communication, berasal dari kata untuk melakukan sesuatu. ${ }^{12}$

communication atau dari kata Pesantren dalam perjalanannya comunis yang berarti sama atau telah menjadi obyek para sarjana sama maknanya atau pengertian barat yang mempelajari Islam. bersama, dengan maksud untuk Pesantren berasal dari kata santri mengubah pikiran, sikap, penerima yang mendapat awalan pe dan dan melaksanakan apa yang akhiran an, berarti tempat tinggal diinginkan oleh komunikator. ${ }^{11}$ Dalam para santri. Istilah santri berasal komunikasi antar komunikator dan dan bahasa Tamil yang berarti guru komunikan harus sama-sama ngaji, dan ada juga yang terfokus sehingga nantinya mengatakan bahwa santri komunikan memberikan feedback mempunyai arti orang yang tahu demi terjalinya sebuah komunikasi buku-buku suci, buku agama, atau yang efektif. Adapun pungsi buku-buku tentang ilmu komunikasi; Informasi, Sosialisasi pengetahuan. (pemasyarakatan), Motivasi, Stetrategi komunikasi \begin{tabular}{rll}
\hline 11 & A.W. Widjaja, Komunikasi: \\
Komunikasi & dan Hubungan Masyarakat
\end{tabular} ( Jakarta: Bumi Aksara, 1993), h. 8. merupakan sebuah perencanaan 12 Ibid, h. 9-10. 
Komunike, Volume XI, No. 2, Desember 2019

atau manajemen dalam proses religiusitas keagamaan masyarakat
penyampaian pesan $\quad$ kepada untuk menjadi insan yang lebih
komunikan atau orang banyak baik menuju generasi umat yang
dengan tujuan pesan tersebut dapat kokoh.
mempengaruhi prilaku seseorang Dalam menapakai langkah sesuai dengan yang diinginkan. religius Robert $H$. Thoules Adapun di dalam al-Quran mengemukakan empat faktor dijelaskan bahwa: religiusitas yang dimasukan dalam "Dan hendaklah ada diantara kelompok utama yaitu: pengaruhkamu sekelompok umat yang pengaruh sosial, berbagai menyeru pada kebaikan, pengalaman, kebutuhan dan proses menyeru kepada yang ma'ruf pemikiran. ${ }^{14}$ dan mencegah dari yang Faktor sosial mencakup semua munkar. Merekalah orang - pengaruh sosial dalam orang yang berjaya"(QS. Ali perkembangan sikap keberagaman, Imran: $104^{13}$ ) yaitu pendidikan orang tua, tradisitradisi sosial dan tekanan-tekanan

Dari uraian ayat $\mathrm{di}$ atas lingkungan untuk menyesuaikan diri dijelaskan bahwa strategi komunikasi dengan berbagai pendapat dan itu tidak lain untuk merubah dan sikap yang disepakati oleh berfungsi untuk mempengaruhi sikap lingkungan.

dan prilaku seseorang. Dalam Faktor lain yaitu pengalaman penelitian ini peneliti menggunakan pribadi atau kelompok pemeluk strategi komunikasi Pondok agama. Pengalaman konflik moral Pesantren untuk memperbaiki

13 QS. Al-Imran ( 3 ): 104.

14 Sururin, IImu Jiwa Agama (Jakarata: PT. Raja Grafindo Persada, 2004 ), h. 79. 
Komunike, Volume XI, No. 2, Desember 2019

dan seperangkat pengalaman batin iman yang harus diterimanya dan emosional yang terikat secara mana yang ditolak. ${ }^{15}$

langsung dengan Tuhan atau Unsur-unsur pesantren ada dengan sejumlah wujud lain pada lima unsur atau elemen yaitu sikap keberagaman juga dapat adanya: Adanya Pondok, Adanya membantu dalam perkembangan masjid, Adanya pengajaran kitabsikap keberagaman. kitab klasik, Adanya santri dan Faktor ketiga adalah Adanya kyai ${ }^{16}$

kebutuhan-kebutuhan yang tidak Tujuan dari pesantren ada dapat dipenuhi secara sempurna, dua bagian yaitu umun dan sehingga mengakibatkan terasa khusus; umum, membimbing anak adanya kebutuhan akan kepuasan didik untuk menjadi manusia yang agama. Kebutuhan-kebutuhan berkpribadian Islam yang dengan tersebut dapat dikelompokkan dalam ilmu agamanya ia sanggup menjadi empat bagian: kebutuhan akan mubalig Islam dalam masyarakat keselamatan, kebutuhan akan cita, sekitar melalui ilmu dan amalannya. kebutuhan untuk memperoleh harga Khusus, Mempersiapkan para santri diri, dan kebuutuhan yang timbul untuk menjadi orang alim dalam karena adanya kematian. ilmu agama yang diajarkan oleh

Faktor terakhir adalah peranan kiyai yang bersangkutan serta yang dimainkan oleh penalaran mengamalkannya dalam verbal dalam sikap keberagaman. masyarakat. ${ }^{17}$

Manusia adalah makhluk berfikir. Salah satu dari akibat pemikirannya adalah bahwa ia membantu dirinya menentukan keyakinan-keyakinan

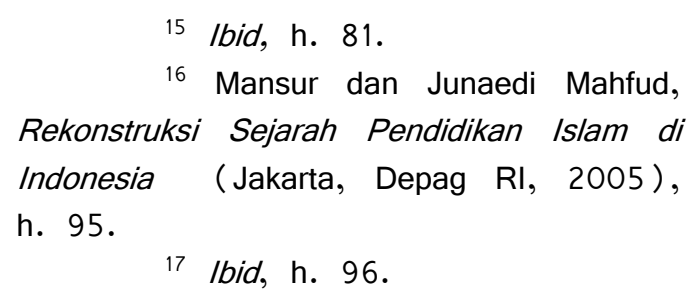
h. 95 .

17 Ibid, h. 96. 
Komunike, Volume XI, No. 2, Desember 2019

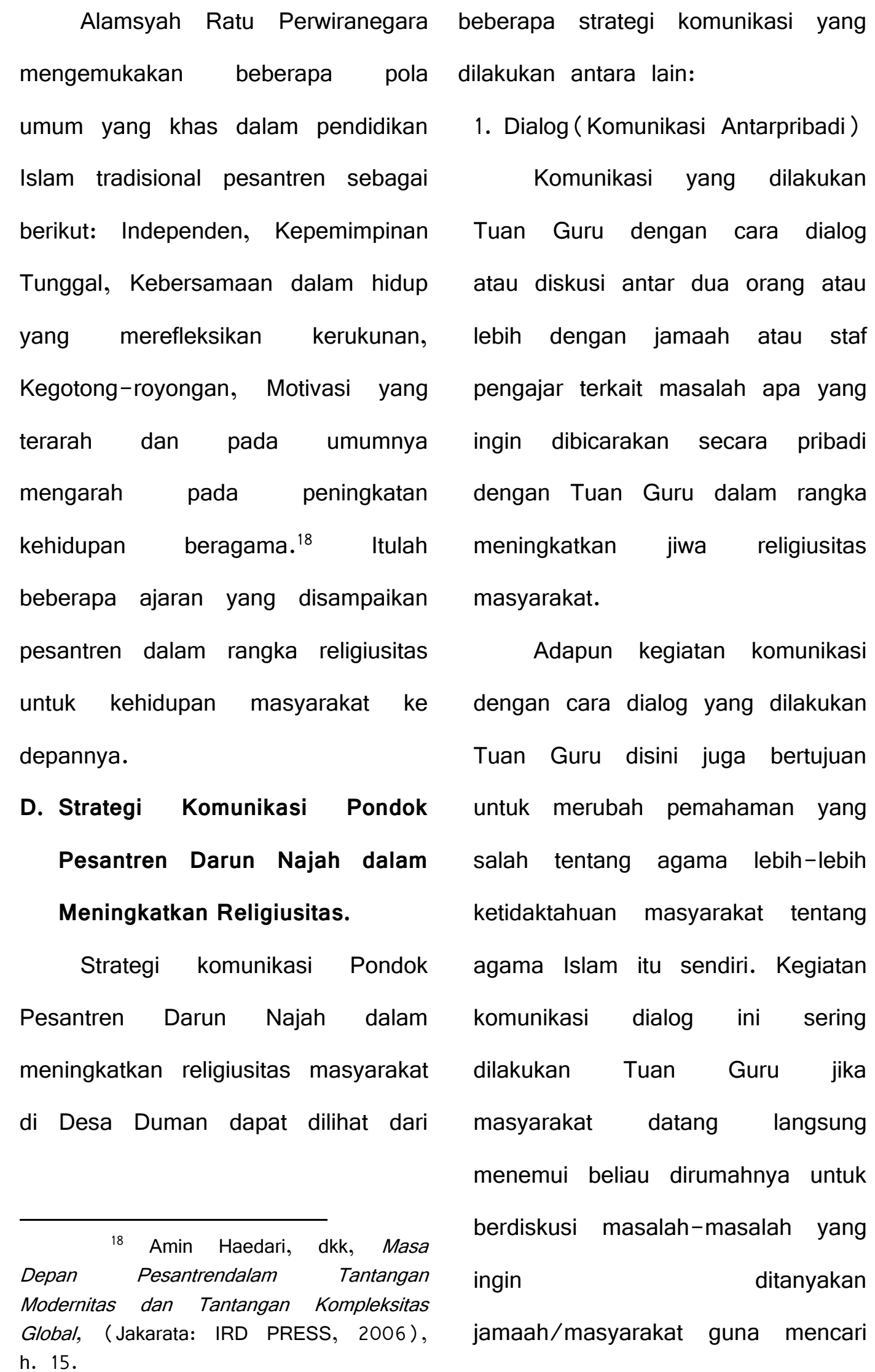
h. 15. 
Komunike, Volume XI, No. 2, Desember 2019

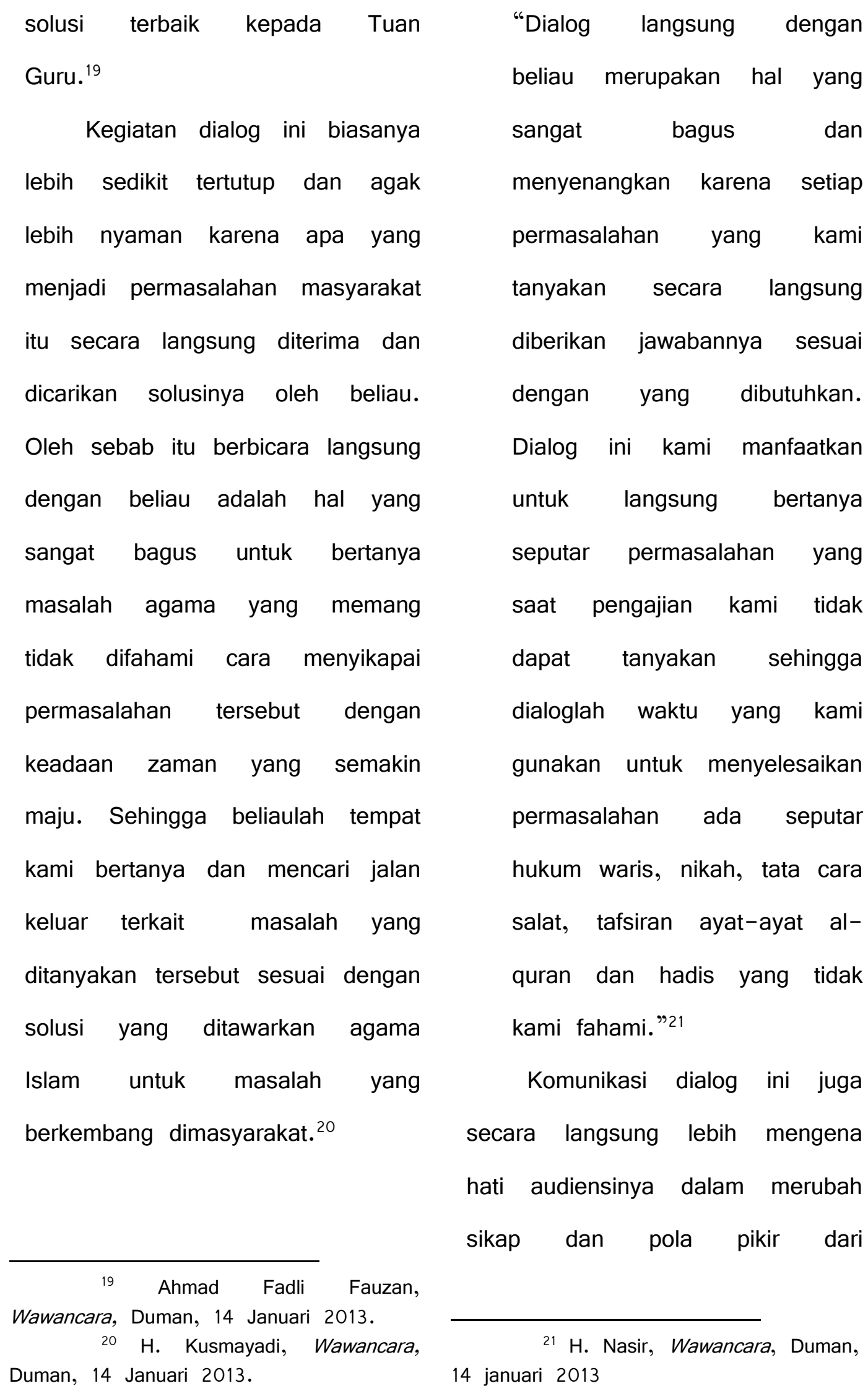


Komunike, Volume XI, No. 2, Desember 2019

masyarakat itu, karena masyarakat

diberikan masukan terkait

permasalahan

kehidupan yang dijalaninya.

Kegiatan inilah yang rutin

dilakukan Tuan Guru apabila

dalam kondisi yang memang sehat

dan siap menerima tamu yang

datang kerumahnya untuk dialog

terkait

masalah-masalah

masyarakat yang berkembang

serta masalah desa dan agama.

2. Pengajian

Kegiatan pengajian memang

sudah menjadi program yang wajib

ada disetiap pondok pesantren

dalam rangka menyebarluaskan

ajaran agama Islam di tengah

masyarakat. Kegiatan pengajian ini

merupakan salah satu strategi

komunikasi Pondok Pesantren

Darun Najah dalam meningkatkan

religiusitas masyarakat di Desa

Duman. ${ }^{22}$

22 Observasi, Jum'at 12 Oktober
Adapun komunikasi yang dilakukan dalam bentuk pengajian ini rutin dilakukan Tuan Guru pada hari Jumat sebelum ba'da Asar dan Minggu sekitar pukul 8 pagi untuk menyampaikan misi dakwah Islamiyah kepada jamaah dalam rangka meningkatkan religiusitas masyarakat. Proses komunikasi melalui pengajian ini rutin dilakukan, namun dalam tanda kutif/ kondisi Tuan Guru sehat. ${ }^{23}$

"Kegiatan pengajian ini saya lakukan karena ini memang sudah menjadi program wajib pondok pesantren dari awal berdirinya sampai sekarang ini dan seterusnya. Dan pengajian ini merupakan kewajiban saya dalam menyampaikan dan menyebarluaskan dakwah islamiyah kepada umat

23 Muhammad Tajun,
Wawancara, Duman, 14 Maret 2012. 
Komunike, Volume XI, No. 2, Desember 2019

muslim, lebih-lebih di daerah menunjukan peran dan fungsinya saya ini sebagai bentuk kepada masyarakat dalam proses kepedulian terhadap kegiatan dakwah islamiyah guna peningkatan religiusitas meningkatkan religiusitas masyarakat kepada Allah masyarakat di desa Duman dan swt." 24 sekitarnya.

Bersamaan dengan waktu 3. Kunjungan

peneliti di lapangan dimana terlihat

Keaktifan Tuan Guru tidak aktivitas komunikasi pengajian hanya aktif pada kegiatan yang diisi oleh Tuan Guru pengajian saja yang dilaksanakan Muhammad Anwar Mz dengan di masjid Nur, akan tetapi beliau materi ceramahnya yang mencakup juga aktif dalam kegiatan masalah aqidah, akhlaq, syariah, masyarakat, pengajian diluar dan mua'amalah, dan tasawuf. kunjungan-kunjungan pribadi ke Pengajian tersebut berlangsung di setiap undangan masyarakat di masjid Nur yang berada di dalam desa Duman maupun diluarnya. ${ }^{26}$ pondok pesantren dan diikuti oleh sejumlah masyarakat setempat dan luar daerah Duman. ${ }^{25}$

Oleh karena itu, proses komunikasi pengajian yang ada di pondok pesantren telah Disamping itu juga Tuan Guru masih sangat aktif mengisi pengajian diluar Duman melalui kunjungan-kunjungan beliau. Hal ini disempatkan untuk menyampaikan dakwahnya terkait dengan kondisi masyarakat yang

24 TGH. Muhammad Anwar, Wawancara, Duman, 18 Januari 2013.

25 Observasi, Jum'at 12 Oktober 2013.

H. Zulkifli, Wawancara, Duman, 24 Januari 2013. 
Komunike, Volume XI, No. 2, Desember 2019

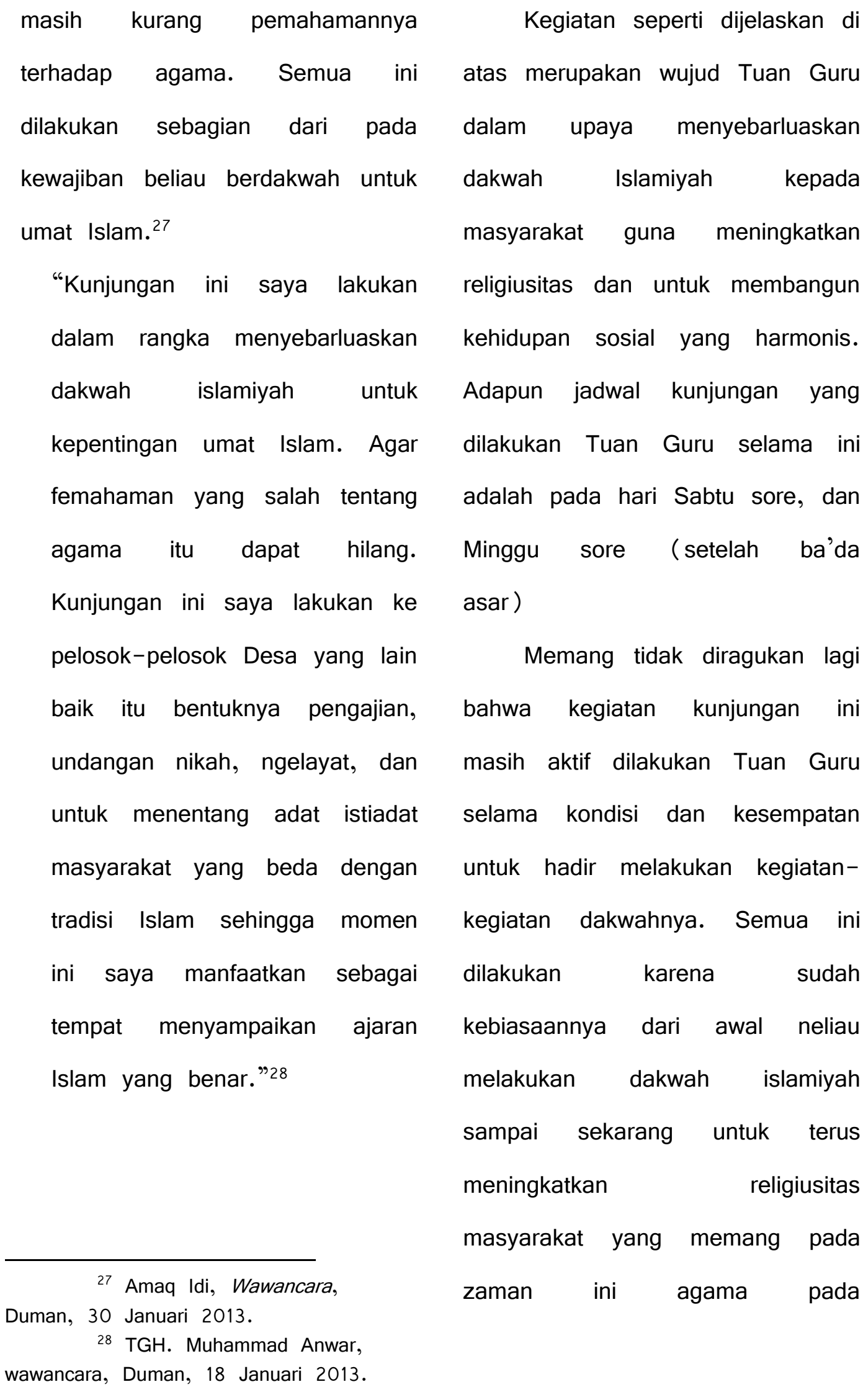


Komunike, Volume XI, No. 2, Desember 2019

masyarakat mulai terkikis oleh masyarakat dan SDM menuju taraf teknologi. ${ }^{29}$

hidup yang lebih baik dan

Kunjungan juga dilakukan mandiri. Pemberian modal ini

Tuan Guru ke wilayah-wilayah dilakukan dengan memberikan pelosok desa yang ada di modal berupa uang untuk kecamatan Lingsar ini dengan membuat usaha dirumah masingtujuan menyebarluaskan ajaran masing dan tidak lupa bagi Islam kepada masyarakat, namun peminjam untuk mengembalikan jika kondisi Tuan Guru dalam modal usaha yang diberikan keadaan sehat untuk pergi Tuan Guru dengan metode cicilan berdakwah.

setiap bulannya. Adapun jumlah

\section{Pemberian Modal Usaha}

Startegi komunikasi selanjutnya yang dilakukan oleh Tuan Guru adalah pemberian modal usaha kepada jamaah yang selalu aktif hadir dalam proses pengajian yang dilaksanakn pondok pesantren setiap hari Jumat dan Minggu tersebut. ${ }^{30}$

Kegiatan pemberian modal usaha kepada jamaah pengajian merupakan salah satu cara guna meningkatkan religiusitas uang yang diberikan sebesar $\mathrm{Rp}$. 500.000 untuk masing-masing perorang jamaah. ${ }^{31}$

Adapun sumber modal uang ini adalah dari Tuan Guru selaku ketua umum baznas NTB untuk mensejahterakan masyarakat. Karena pemberian modal ini merupakan bentuk program kerja Tuan Guru selaku ketua umum dan ini semua hanya dipriorotaskan kepada jamaahjamaah pengajian yang ada di

30 Observasi, Jum'at 12 Oktober. Wawancara, Duman, 18 Januari 2013. 
Komunike, Volume XI, No. 2, Desember 2019

NTB ini. Karena hanya yang aktif mengaji saja di berikan modal usaha untuk membangun ekonomi hidupanya. Pemberian modal usaha ini sudah berjalan selama Tuan Guru menjabat sebagai ketua umum BAZNAS NTB. ${ }^{32}$

Pemberian modal ini memberikan dampak yang positif terhadap kehidupan masyarakat agar bisa bersaing dalam kegiatan ekonomi. Modal usaha pun diberikan dengan cuma-cuma, namun dengan syarat masyarakat mau berusaha untuk mengembangkan usahanya guna meningkatkan kehidupannya yang lebih baik. Dengan kegiatan seperti ini masyarakat menjadi terbantu untuk hidup mandiri tanpa menunggu bantuan dari pemerintah.

"Di samping itu juga kita tidak munafikan bahwa kadang-

32 Amaq Rudi, Wawancara, Duman, 24 Januari 2013. kadang jamaah itu rajin ikut mengaji hanya untuk mendapatkan modal uang tersebut. Hal ini juga dirasakan Tuan Guru namun selama mereka masih bisa mengembalikan modal yang diberikan kepada Tuan Guru, hal itu sangat diwajarkan sebagai bentuk usaha masyarakat. Namuan itu juga tetap ada imbasnya dari pengajian yang diberikan dan memberikan dampak yang positif bagi masyarakat tersebut." 33

5. Pemberian Zakat pada Delapan Golongan

Strategi komunikasi berikutnya guna meningkatkan religiusitas masyarakat di desa duman yaitu pembagian zakat kepada jamaah pengajian yang termasuk dalam

33 H. Hadi, wawancara, Duman, 12 Februari 2013. 
Komunike, Volume XI, No. 2, Desember 2019

golongan delapan (orang-orang yang berhak menerima zakat).

Pemberian zakat ini adalah bentuk dari strategi beliau dalam meningkatkan religiusitas

masyarakat. Dengan diberikannya zakat ini jamaah pengajian itu rajin untuk mengaji, tidak ragukan bahwa imbasnya kepada jamaah sangat besar untuk kepentingan mereka. Dengan rajinnya mengaji otomatis pemahaman masyarakat tentang agama semakin meningkat. ${ }^{34}$

Sebagai pimpinan BAZNAS (Badan Amil Zakat Nasional) NTB mengungkapkan kepada jamaah bahwa untuk jamaah yang ikut pengajian rutin diberikan zakat oleh Tuan Guru Anwar. Hal ini dilakukan sebagai bentuk kepedulian Tuan Guru bagi jamaah yang setia mengaji kepadanya sesuai dengan keadaan

34 Kamaludin, wawancara, Duman, 7 Februari 2013. ekonomi jamaah, sehingga yang berhak saja mendapatkan zakat yang dibagikan. ${ }^{35}$

"Pemberian zakat ini memang saya berikan kepada jamaah pengajian yang memang kurang mampu/bisa dikatakan mereka yang berhak menerima zakat ini. Adapun sumber zakat ini adalah dari dana BAZNAS sendiri selaku pengumpul uang zakat para pejabat dilingkup pemerintahan untuk diberikan kepada yang rakyat yang berhak mendapatkannya. Jumlah zakat yang diberikan adalah sesuai dengan ketentuan Allah jumlah yang wajib zakat. Hal ini merupakan bentuk kewajiban menjalankan perintah Allah untuk meningkatkan religiusitas masyarakat. $" 36$
35 Observasi, Jum'at 28

Desember 2012.

$36 \mathrm{TGH}$. Muhammad Anwar, Wawancara, Duman, 18 Januari 2013. 
Komunike, Volume XI, No. 2, Desember 2019

Oleh karena itu, pembagian

Pertama;

Terjalinnya

zakat ini merupakan kewajiban

Komunikasi antar Lembaga atau

beliau sebagai umat Islam untuk

Internal Pesantren, dampak positif

wajib memberikan sebagian

dari strategi komunikasi pondok

hartanya untuk saudara yang

Pesantren Darun Najah Duman

kurang mampu sesuai dengan

dapat kita lihat di internal

ajaran agama Islam, bahwa zakat

pesantren bahwa komunikasi

adalah hukumnya wajib sebagai

antara lembaga formal dan

bentuk untuk mensucikan harta

lembaga non formal pesantren

umat Islam di sisi Allah SWT.

terjalin dengan baik, baik itu

Dakwah yang dilakukan oleh

pimpinan pesantren, para guru

Tuan Guru Anwar di lapangan

dan ustadz/ustadzah dalam

ternyata tidak didukung dengan

menjalani kegiatan sehari-hari di

partisipasi

dari

para

pondok pesantren.

pengurus/anggota yayasan seperti

Keramah tamahan ini sudah

guru/ustadz dan santri untuk ikut

tertanam dalam diri setiap serta berdakwah

dalam

pengurus yayasan, karena peran

meningkatkan

religiusitas

masyarakat. ${ }^{37}$

dari Tuan Guru sendiri sebagai

peimpinnan tertinggi disini

E. Dampak Positif Strategi mengajarkan betapa pentingnya Komunikasi Pondok Pesantren menjaga dan memelihara

Darun Najah dalam Meningkatkan kedamaian dan ketenangan serta

Religiusitas Masyarakat. persaudaraan antar pengurus

lebih-lebih sesama umat muslim. ${ }^{38}$

37 Observasi, Minggu 21 Oktober

38 Mbak Ririn, Wawancara,

Duman, 18 Januari 2013. 
Komunike, Volume XI, No. 2, Desember 2019

Komunikasi yang dibangun dengan mengedepankan ukhuwah islamiyah dapat terlihat dari cara pengurus yayasan berbicara dengan sopan, santun, dan penuh dengan lelucon. Semua itu terjadi setiap hari kerja pondok pesantren.

Hubungan baik yang terjalin di internal pondok pesantren tidak lepas dari figur seorang pemimpin seperti Tuan Guru Anwar yang memiliki kharisma tersendiri yang penuh dengan lelucon, tegas, dan cerdas. Ini semua terlihat dari keseharian beliau selama di pondok maupun dalam pengajian. Semua itu tidak lepas dari fungsi seorang pemimpin untuk menjaga kondisi organisasi yang dibangun agar tetap kokoh dan penuh dengan kearifan dalam setiap bagian-bgaian terpenting pondok pesantren dengan ajaran ukhuwah islamiyah.
Kedua; Terciptanya Hubungan Religius antar Masyarakat, startegi komunikasi yang dilakukan oleh pondok pesantren Darun Najah Duman adalah dalam rangka meningkatkan religiusitas masyarakat. Dengan adanya pondok pesantren ditengah masyarakat memiliki dampak yang baik seperti yang kita jumpai di desa Duman bahwa hubungan religius antar masyarakat terjalin dengan baik.

Terciptanya hubungan religius tersebut tidak lepas dari upaya pondok dalam menyebarluaskan ajaran Islam yang memang mengajarkan tentang besarnya manfaat silahturrahmi antar manusia. Hal tersebut terlihat dari keseharian masyarakat Duman dalam kehidupan sosial seperti memuliakan tamu dan terjalinnya persaudaraan yang baik antar masyarakat. Semua itu terlihat jelas dari dampak keberadaan 
Komunike, Volume XI, No. 2, Desember 2019

pesantren sesuai dengan ajaran
Islam seperti yang disampaikan
Tuan Guru bahwa betapa
pentingnya menjalin silahturrahmi
untuk kehidupan sehari-hari. ${ }^{39}$

Adapun bentuk lain dari religisitas antar masyarakat Duman seperti selalu diadakan yasinan bersama setiap malam sabtu dimasjid, wiridan bersama pada malam Jum'at dipondok. Ha inilah yang setiap harinya terjadi dikehidupan masyarakata Duman. Hubungan sosial pun tidak lepas dari peran penting keberadaan pondok pesantren Darun Najah Duman dalam meningkatkan religiusitas masyarakat. Ini merupakan dampak yang sangat terasa sekali karena berkat ajaran yang ada di pondok pesantren memiliki nyawa sendiri bagi kehidupan sosial masyarakat Duman untuk selalu

39 Observasi, Kamis 14 Januari 2013. terjalin dengan baik hubungan antar masyarakatnya. ${ }^{40}$

Ketiga;

Terciptanya Keharmonisan di Desa Duman, Sehubungan dengan keberadaan peneliti di lapangan dampak positif komunikasi pondok pesantren Darun Najah Duman sesuai dengan peran dan fungsinya telah berhasil menciptakan keharmonisan di desa Duman. Keharmonisan yang terjalin antar masyarakat karena imbas dari peran dan fungsi pondok pesantren. Kondisi inilah yang membuat kehidupan masyarakat Duman menjadi harmonis dan religius. Ini semua dibuktikan dengan keadaan masyarakat aktif dengan kegiatan sosial contohnya gotong royong dan kegiatan begawe, keadaan masyarakat jauh dari konflik agama maupun sesama muslim, $40 \quad$ H.
Duman, 24 Januari 2013. 
Komunike, Volume XI, No. 2, Desember 2019

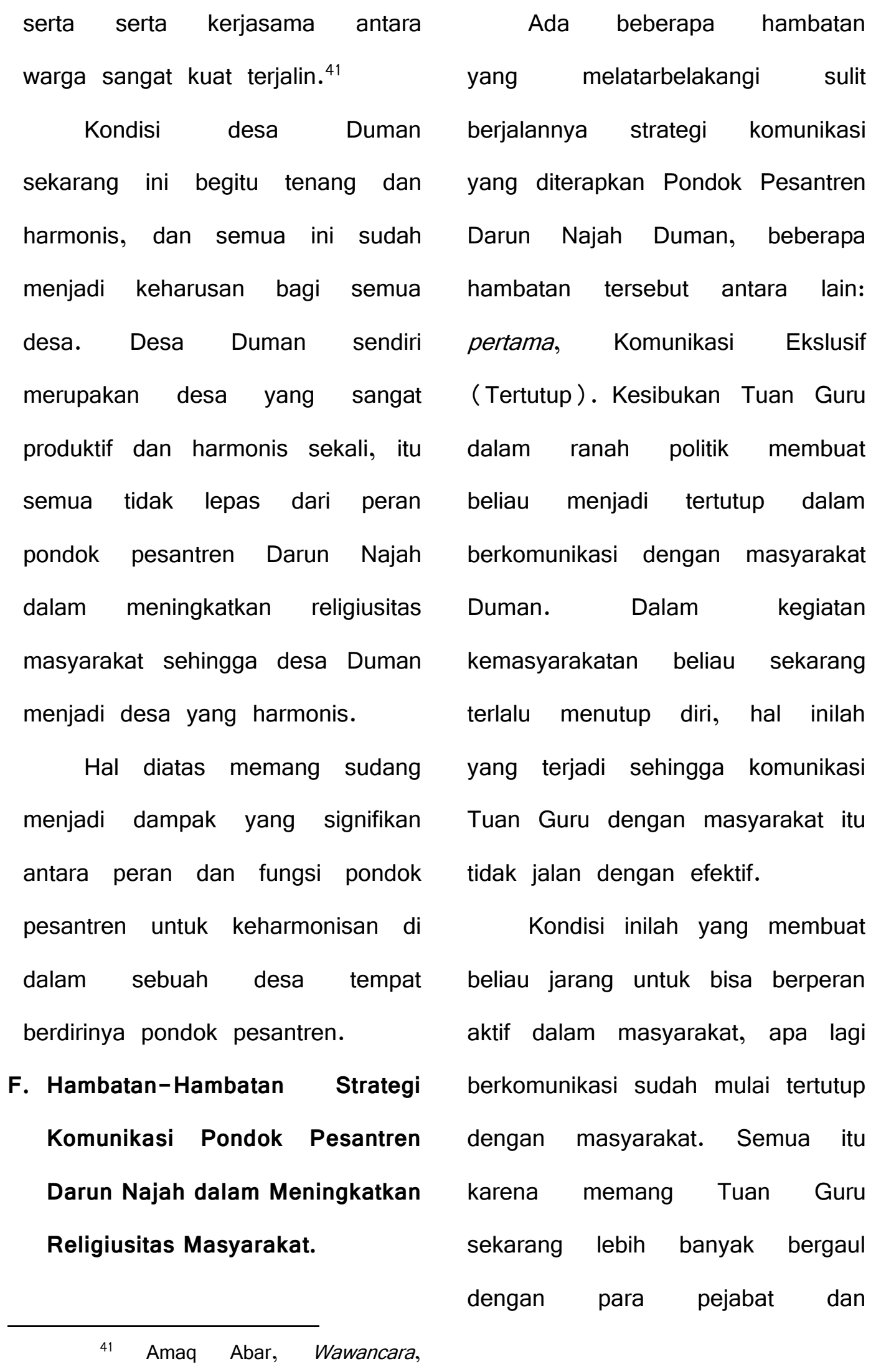

Duman, 24 Januari 2013. 
Komunike, Volume XI, No. 2, Desember 2019

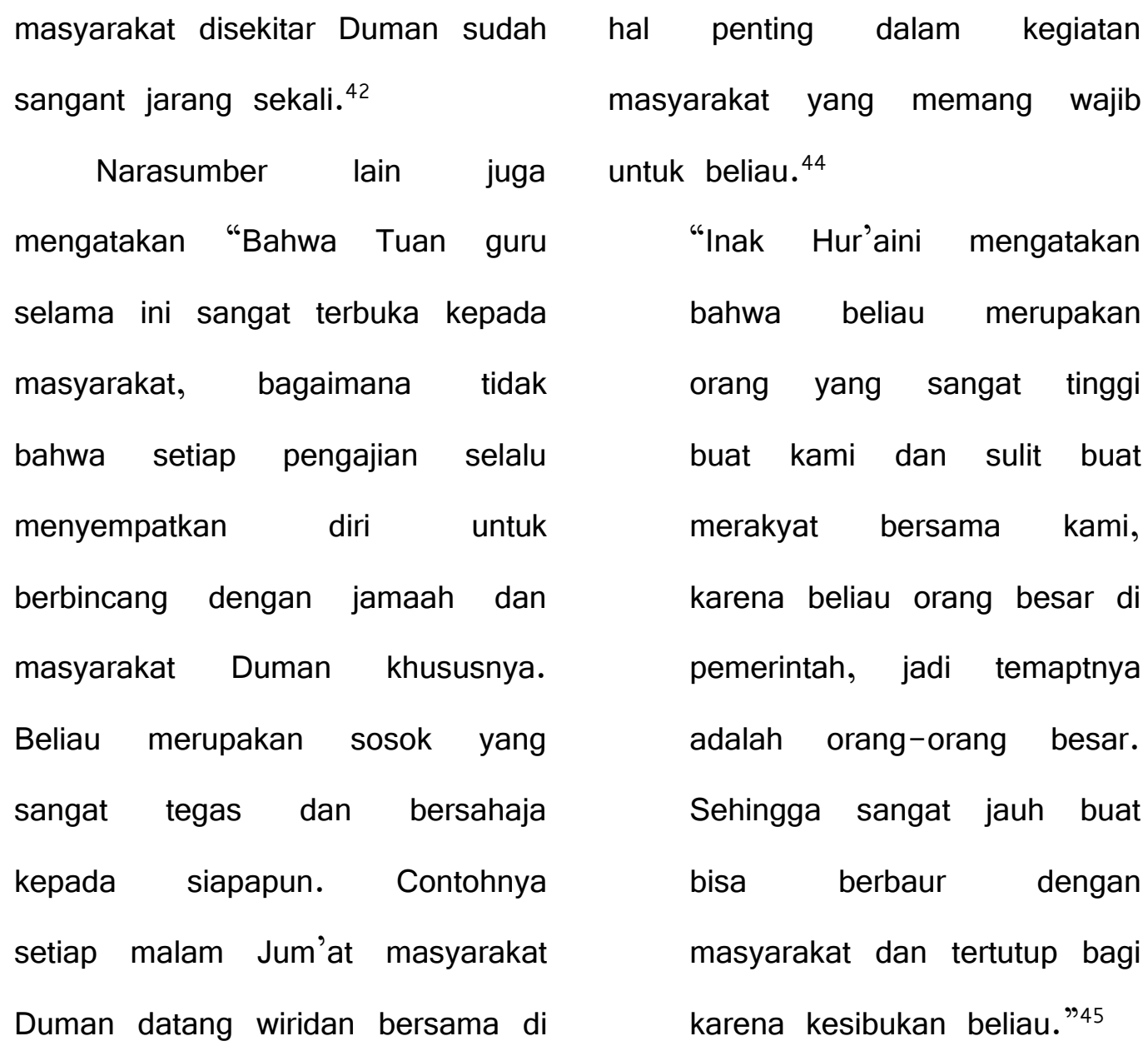

pondok pesantren." 43

Di samping itu juga bahwa

Oleh karena itu, Tuan Guru kesibukan beliau diluar pondok Anwar sudah mulai tertutup pesantren (menjadi ketua komunikasinya dengan masyarakat BAZNAS ) membuat dirinya Duman. Dan sudah menjadi menjaga jarak dan tidak terlalu keharusan beliau untuk sibuk berbaur dengan masyarakat dengan keaadaannya dan waktu apapun. Akan tetapi hanya hal- untuk berkomunikasi dengan

42 Ustadz Tazhir, Wawancara, Duman, 22 Februari 2013.

43 Inak Mahnep, Wawancara, Duman, 12 Januari 2013.
44 M. Rusmin, Wawancara, Duman, 21 februari 2013

45 Hur'aini, Wawancara, Duman, 08 Januari 2013. 
Komunike, Volume XI, No. 2, Desember 2019

masyarakat dirasakan sangat sulit sekali.

Kedua, Kurangnya Waktu

Luang Tuan Guru, Hambatan komunikasi yang terjadi di pondok pesantren dengan masyarakat sekitarnya berakar dari realitas ini bahwa Tuan Guru Anwar memiliki sedikit waktu berada di pondok pesantren dikarenakan kegiatan beliau di pemerintahan yang begitu padat dengan jadwal kerja dan undangan untuk mensosialisasikan program kerja kepada rakyat NTB terkait jabatan beliau di pemerintahan sebagai ketua umum BAZNAS (Badan Amil Zakat Nasional).

Dari hasil wawancara dengan narasumber, bahwa keaktifan Tuan Guru dengan pekerjaannya menyebabkan terjadinya kesenjangan waktu luang dengan kegiatan pondok pesantren dan sosial masyarakat. Bagaimana komunikasi yang dulu dijalin begitu dekat kini sudah mulai renggang, sehingga merujut kepada sepinya kegiatan yang sudah menjadi keharusan di pondok pesantren seperti pengajian rutin.

Kurang waktu luang inilah yang menjadi hambatan strategi komunikasi pondok pesantren Darun Najah dalam meningkatkan religiusitas masyarakat di desa duman kecamatan lingsar lombok barat.

Ketiga, Sibuk di Birokrasi atau Politisi, Adapun hambatan komunikasi yang terjadi di pondok pesantren Darun Najah Duman selama ini yang dirasakan pengurus yayasan adalah kesibukan Tuan Guru di ranah politik/pemerintahan. Tuan Guru selama ini sulit untuk bisa bertemu dengan masyarakat karena jarang dirumahnya. Sehingga pengajian yang dilakukan pondok pesantren kini mulai sepi dari jamaahnya, ini dirasakan 
Komunike, Volume XI, No. 2, Desember 2019

$\begin{array}{lrrrr}\text { sekali oleh pengurus yayasan. } & \text { begitu dekat kini mulai jauh } \\ \text { Kesibukannya } & \text { inilah yang membuat } & \text { karena sibuk dan tidak punya } \\ \text { masyarakat } & \text { Duman } & \text { mulai } & \text { waktu luang buat masyarakat. }{ }^{47} \\ \text { menghilang dan sangat jarang } & \text { Oleh sebab itu, kondisi di } \\ \text { mengikuti kegiatan pengajian } & \text { atas merupakan kendala yang } \\ \text { rutinan pondok pesantren. Tuan } & \text { signifikan terhadap kegiatan yang } \\ \text { Guru Anwar sendiri selaku } & \text { dilakukan Tuan Guru yang }\end{array}$

pimpinan pondok pesantren berakibatkan jarak anatara

merasakan hal ini, namun beliau masyarakat setempat terjadi.

pernah berkata bahwa Keempat, Materi Pengajian

keinginannya untuk berhenti di tidak Representatif dengan

pemerintahan, akan tetapi Audience, Selanjutnya bahwa

gubernur sendiri yang meminta hambatan komunikasi yang

beliau menjadi penasehatnya menonjol dalam setiap pengajian

dibiroksrasi. ${ }^{46} \quad$ yang dilakukan Tuan Guru adalah

Dari hasil wawancara peneliti materi pengajian yang tidak dengan masyarakat setempat representatif (tidak sesuai) bahwa kesibukan beliau ini dengan pengajian pada umumnya. dirasakan sekali, masyarakat Adapun materi yang disampaikan terkadang berpikir untuk janganlah Tuan Guru itu persis dengan terlalu sibuk dipemerintahan karena materi kuliah yang biasa akan berakibat bisa melupakan mahasiswa dapat di kampus. masyarakatnya. Sehingga Sedangkan jamaah pengajian ratasilahturrahmi yang selama ini rata kebanyakan orang tua. Dalam

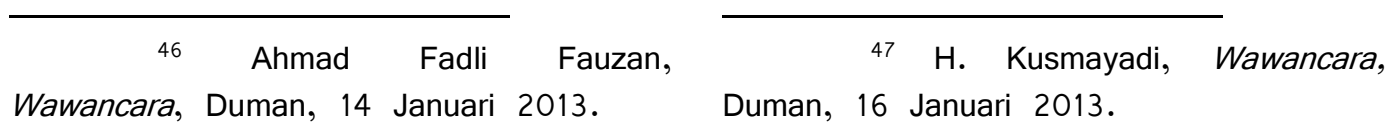


Komunike, Volume XI, No. 2, Desember 2019

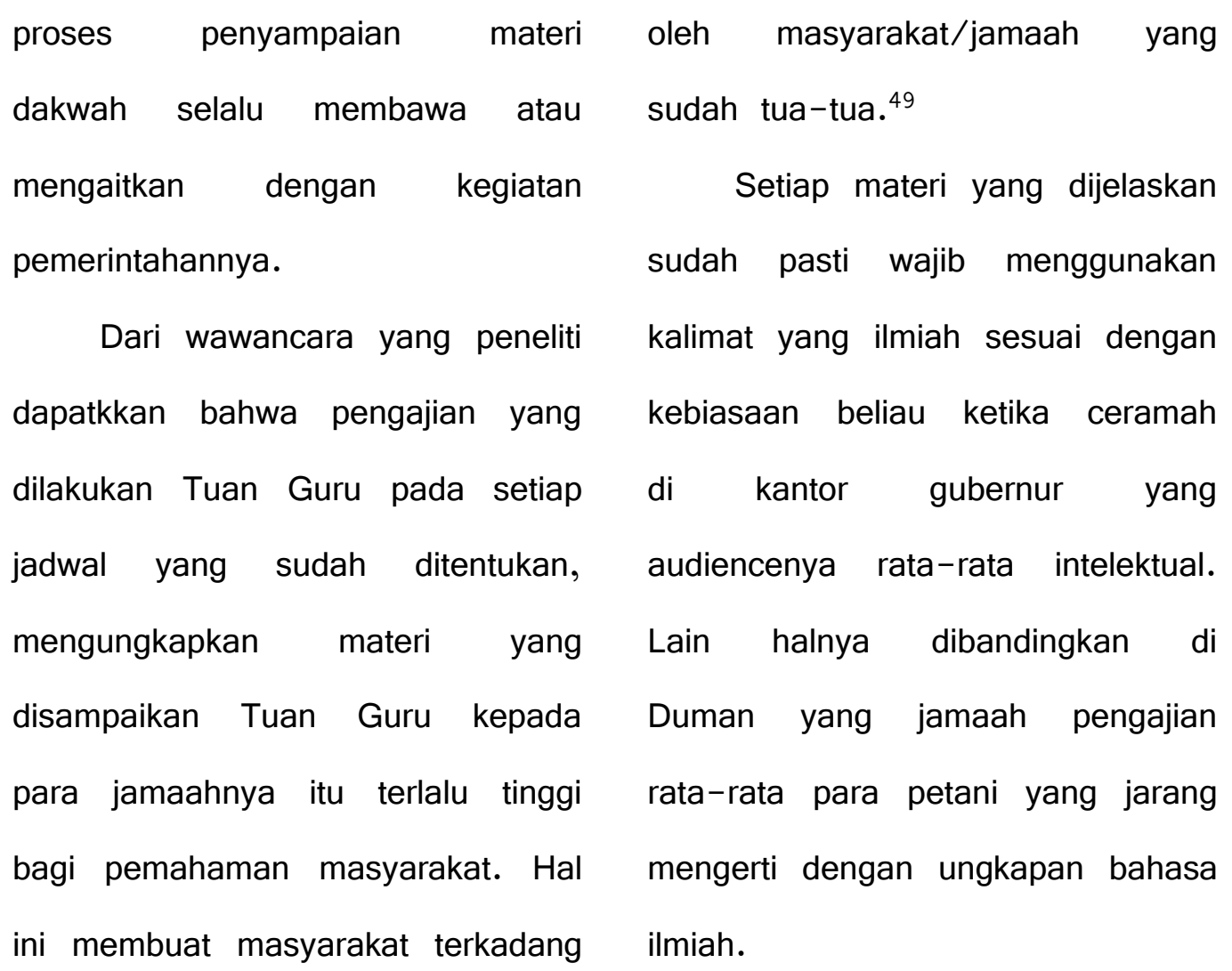
binggung dengan materi yang

Terkadang juga setiap terlalu tinggi untuk diberikan kalimat yang disampaikan Tuan kepada masyarakat. ${ }^{48}$ Adapun juga Guru terhadapap jamaah/materi hambatan lain yang ada saat yang tidak dimengerti tersebut penyampaian materi pengajian secara langsung dijelaskan kembali sebagai berikut: Terlalu Ilmiah, oleh sang istri Tuan Guru dengan Kegiatan pengajian mingguan yang sejelas-jelasnya agar jamaah dilakukan di pondok pesantren dan faham dengan yang dimaksudkan disampaikan Tuan Guru terkadang beliau. ${ }^{50}$ sering menggunakan bahasa yang ilmiah dan sulit untuk difahami

48 Hur'aini, Wawancara, Duman, 09 November 2012.

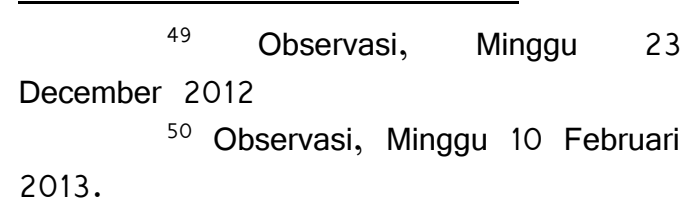
2013. 
Komunike, Volume XI, No. 2, Desember 2019

Bahasa Indonesia, Seperti jamaah dengan bahasa Indonesia yang dijelaskan di atas, kebiasaan Tuan Guru berbicara dengan para stafnya dikantor dan pidato di kantor gubernur selalu menggunakan bahasa Indonesia mengaitkan dengan kegiatan dalam setiap ceramah yang pemerintahannya atau bisa dilakukan dalam proses pengajian dikatakan materinya tidak jarang rutin pondok pesantren. memiliki unsur-unsur politik. Proses penyampaian pesan Proses pengajian yang dilakukan dakwah islamiyah melalui tersebut terkadang digunakan Tuan pengajian rutinnya bahwa setiap Guru sebagai tempat sarana kalimat per kalimat materi kampanye politik untuk ceramah itu menggunakan bahasa mempengaruhi jamaah. Indonesia untuk didengarkan oleh Begitu pula dengan jamaah pengajian. Sehingga keberadaan peneliti bahwa di bahasa tersebut terkadang hanya tahun yang dekat dengan dimengerti oleh jamaah yang pemilihan gubernur periode 2013masih muda, namun bagi jamaah 2018 Tuan Guru selalu yang memang sudah tua-tua sulit menggunakan kesempatan untuk untuk bisa menangkap pesan menyampaikan materi-materi beliau. Begitu juga dengan hal ini pengajian yang selalu dikaitkan bahwa istri dan anaknya juga dengan keegiatan kampanyenya sering sebagai sarana untuk untuk memilih kembali Tuan Guru menjelaskan kembali maksud dari Bajang sebagai gubernur NTB. materi yang tidak dimengerti 
Komunike, Volume XI, No. 2, Desember 2019

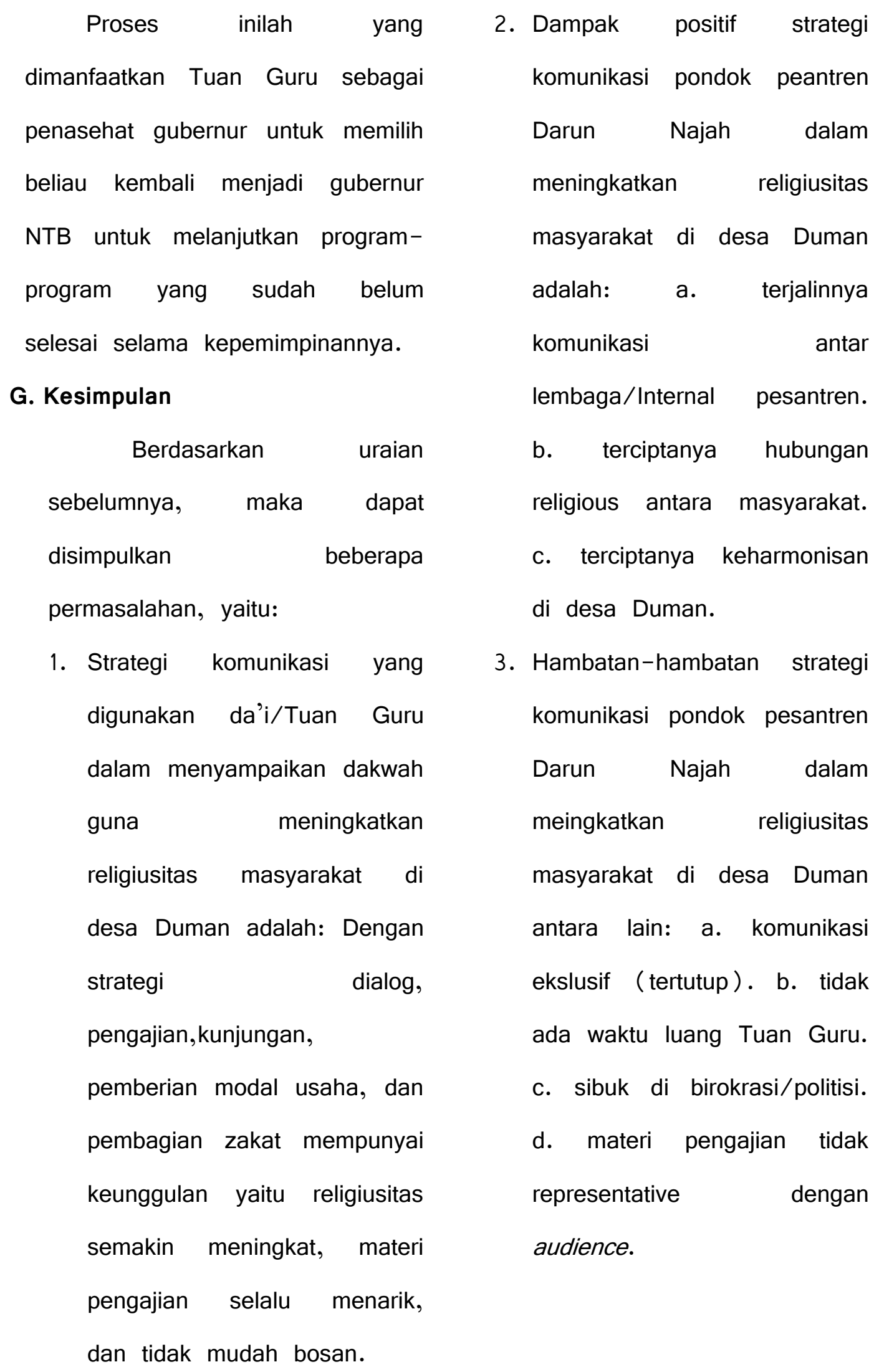


Komunike, Volume XI, No. 2, Desember 2019

\section{Daftar Pustaka}

A.W. Widjaja, Komunikasi: Mansur dan Junaedi Mahfud, Komunikasi dan Hubungan Rekonstruksi Sejarah

Masyarakat, Jakarta: Bumi Pendidikan Islam di Indonesia, Aksara, 1993. Jakarta, Depag RI, 2005.

Abdul Mujid dan Yusuf Mudzakkir, Mansur dan Mahfud Junaedi, IImu Pendidikan Islam, Rekonstruksi Sejarah

Jakarta: Kencana Prenada Pendidikan Islam di Indonesia, Media. 2006. Jakarta: Departemen Agama Amin Haedari, dkk, Masa Depan RI, 2005.

Pesantrendalam Tantangan Onong Uchjana Effenndy, IImu dan Modernitas dan Tantangan komunikasi teori dan praktek, Kompleksitas Global, Jakarata: Bandung: PT Remaja IRD PRESS, $2006 . \quad$ Rosdakarya, 2007.

DEPDIKBUD, Kamus Besar Bahasa ururin, IImu Jiwa Agama, Jakarata: Indonesia, Jakarta: Balai PT. Raja Grafindo Persada, Pustaka, 2002. 